\title{
THE EFFECT OF ETHICS ON BANKS' FINANCIAL PERFORMANCE
}

\section{Radek Halamka, Petr Teplý}

\begin{abstract}
In this paper, we contribute to the literature focusing on ethics in banking from both theoretical and empirical point of view. We argue that the recent business of the global banking industry is not sustainable and we believe that ethical banking may represent one of the alternative models. In the empirical section, we investigate how ethics in the banking business models affects their financial performance. We identified 69 ethical banks and compared them with conventional banks using Bankscope data of more than 80,000 bank-year observations for the 2003-2013 period. We apply the Within-Between estimation method to bank financial indicators of Return on Assets, Return on Equity and their respective volatilities. We conclude that ethical banks report significantly lower volatility in Return on Equity than their conventional counterparts. In addition, the hypothesis that ethical banks would have higher profitability than their peers is not rejected.
\end{abstract}

Keywords: bank, ethics, financial performance, bank business models, profitability JEL Classification: A13, B12, B16, G21, Q56

\section{Introduction}

The application of ethical standards in banking is not a new topic. Over the last 20 years, questions about ethics and sustainability of the banking industry have been frequently raised. In the aftermath of the 2007-2009 global financial crisis, we saw a regulatory response to improper banks' behaviour that has materialized in amoral and usually quantifiable measures, such as increased financial regulation or stricter limits for asset class exposures. Arguably, only little has been done to change the banking culture that ultimately decides about banks' operations. Banking culture cannot be changed through regulation; it has to be altered from within banking institutions. However effective regulation of financial markets providing the right incentives may seem impossible (Acharya et al., 2010; Klinger and Teplý, 2014), financial authorities, investors and foremost the public can create demand and impetus for the change.

The recent wave of digitalization in financial services can play an important role in redefining the banking culture. We expect that banks will have to fight over their

* Radek Halamka, Institute of Economic Studies, Faculty of Social Sciences, Charles University in Prague, Prague, Czech Republic (radek.halamka@gmail.com);

Petr Teplý, Department of Banking and Insurance, Faculty of Finance and Accounting, University of Economics in Prague, Prague, Czech Republic (petr.teply@vse.cz).

This research was supported by the Czech Science Foundation (Projects No. GA 14-02108S and No. GA 15-00036S) and University of Economics in Prague (Project VŠE No. IP 100040). 
customers with more flexible Fintech companies ${ }^{1}$ and an increased supply of variety of products is likely to step up customer demands on banking services. Good and proper customer care will not be sufficient any longer as clients will request higher control over their money. To retain current clients, banks will need to demonstrate their reliability that deposits and savings are used in accordance with customers' values (EBF, 2015). With remaining mistrust of global banking industry, increasing non-bank competition and changing clients' preferences, we believe that ethical banking may represent such an alternative.

This paper puts against each other two groups of banks. The first group includes banks that set their standards on the base of required compliance; and economic efficiency is far the most important factor informing their decisions ("conventional banks"). The second group encompasses banks that use ethical framework throughout their business model and deliberately include moral judgements in decision-making ("ethical banks").

Although there may be prevailing perception of economics as by definition amoral, we argue that this misconception has developed only recently. In fact, the father of modern economic taught, Adam Smith, based his thinking on combination of moral sentiments (Smith, 1759) and self-interest (Smith, 1776). Similarly, Sen (2000) explains that economics developed from ethics and only in modern perception could be divided into two branches - engineering and ethics-related. It is only since quantification of economics that the engineering approach has extensively outweighed the later. In spite of that, ethical concepts can still be very useful for economics and banking as well. For instance, Kant's Formula of Universal Law and Formula of the End in Itself can provide us with an instructive framework for dealing with externalities and sustainability (Kant, 1785). ${ }^{2}$

Certain scepticism about applicability of the theory into practice is understandable, especially if we think of its financial viability in the competitive sector of banking industry. This paper endeavours to address the reservations, that we initially also shared, and research differences in financial performance between conventional and ethical approach to banking. We test a hypothesis that may seem most intuitive: "Ethical banks are less profitable in terms of Return on Asset and Return on Equity but they demonstrate lower volatility in time."

The rest of the paper is organized as follows: the next section introduces ethical banks with their main specifics. In Section 3 we introduce our dataset and variables. Section 4 discusses applied methods in detail. In Section 5 we test our hypothesis, summarize key findings and discuss further research opportunities. Finally, Section 6 concludes the paper and states final remarks.

\section{Theoretical Background}

There are banks that do not perceive ethics as an obstacle to their performance or operations and incorporate it throughout their organization. The so-called ethical banks do not have a unified business model since they emerge from different historic backgrounds and reflect specific conditions of the markets they serve. There are banks that derive their ethics from anthroposophy and banks that were built around commitment to serve communities that

$1 \quad$ EBF (2015, p.11) defines "Fintech" as financial technology companies using software to provide financial services, generally presented as start-ups.

2 After relaxing some of very strict Kant's assumptions. 
established them, there are green banks as well as banks fighting poverty of unbanked through micro-financing in emerging economies. They all put people before profit and share values of sustainability, transparency, diversity and inclusion (United Nations Environment Programme, 2015).

Table 1 | Principles of Sustainable Banking

\begin{tabular}{|l|l|c|}
\hline & \multicolumn{1}{|c|}{ Principles of Sustainable Banking } & Dimensions \\
\hline Principle 1 & Triple bottom line approach at the heart of the business model & F, S, E \\
\hline Principle 2 & $\begin{array}{l}\text { Grounded in communities, serving the real economy and enabling } \\
\text { new business models to meet the needs of both }\end{array}$ & F, S \\
\hline Principle 3 & $\begin{array}{l}\text { Long-term relationships with clients and a direct understanding } \\
\text { of their economic activities and the risks involved }\end{array}$ & F \\
\hline Principle 4 & Long-term, self-sustaining, and resilient to outside disruptions & G \\
\hline Principle 5 & Transparent and inclusive governance & S, G \\
\hline Principle 6 & All of these principles embedded in the culture of the bank & \\
\hline
\end{tabular}

Note: Abbreviations for dimensions: F - financial, S - social, E - environmental, G - corporate governance. Source: Authors based on Global Alliance for Banking on Values (2014)

Several member organisations have been established to connect likely-minded leaders in the field with membership usually conditioned by meeting a certain set of principles. The six Principles of Sustainable Banking as synthesized by Global Alliance for Banking on Values (GABV) serve us for primary classification of ethical banks and help to distinguish them from conventional banks. ${ }^{3}$ Although the principles predominantly summarise what connects all GABV's 27 member banks they could be generally applied across the whole sector. ${ }^{4}$ There is also apparent similarity between the Principles and other sustainability frameworks used in economics and finance. Table 1 summarizes the Principles and outlines the overlap with Triple Bottom Line where we identify financial (F), social (S), and environmental (E) dimensions and environmental, social and corporate governance that adds up the governance dimension $(\mathrm{G})$.

Since we often use the term 'sustainable' interchangeably with 'ethical' we owe the reader an explanation why. Relaxing several strict assumptions, it is conceivable to derive the concept of sustainability from the building blocks of modern moral philosophy

3 We cannot avoid certain level of simplification as both categories cover wide variety of bank business models, different historic backgrounds or market conditions that makes edges necessarily dull.

4 Other organizations that provide definitions of ethical banking are the European Federation of Ethical and Alternative Banks (FEBEA), Institute for Social Banking and International Association of Investors in the Social Economy. "ethical banking" is not a generally accepted term and each of the mentioned organizations gives the concept a different name, e.g. social or values based banking. Since the underlying principles do not substantially differ we use the terms interchangeably. 
- Kant's Formula of Universal Law and Formula of the End in Itself ${ }^{5}$. The concept of universality prescribes that an action shall not contradict its maxim when applied universally so that its consequences remain compatible with the original intentions ${ }^{6}$ while Formula of the End in Itself directs all attention to humanity that must always be the ultimate goal. Both the laws are usually utilized unconcerned with time, however, once we combine the formulas of universality and humanity and project them in time we get nothing less than the concept of sustainability. A sustainable action could then be defined through the ethical system as one which, being univerzalised across population and time, does not directly or indirectly harm humanity. It is needless to say that an indirect harm can be done through creating negative social conditions as well as environmental pollution.

Reflecting the humanity formula, ethical banks do not have profitability as their primary goal. Rather they aim to serve human needs, that include healthy environment, and financial sustainability is a necessary condition in achieving that. The financial sustainability, therefore, does not mean unconditional profit maximisation and long-term resiliency is always preferred over short-term performance. Profitability and volatility remain highly important indicators but ethical banks put at least as strong emphasis on other measures of financial performance that to a certain extent overlap with the social dimension of the business. Loan loss ratios or share of assets exposed to real economy may serve as examples of such measures.

That ethical banks do transfer the theory into practice can be further showcased on their credit decision-making. The banks do not base their decisions strictly on financially motivated factors but very often include consequences for the society and environment to the framework and aim to internalise the externalities. They usually ask for purpose of a required loan and then assess if it fits their ethical standards. For simple cases the banks have developed positive and negative criteria ${ }^{7}$, when a case falls to a grey zone in between decisions are often made in deliberation. In many cases social or environmental can outweigh the financial dimension. For instance, financing leveraged buyout would likely be ruled out as it is usually motivated by purely financial and no social gains. Some ethical banks also offer better terms on a mortgage if the respective building is more environmentally friendly.

Corporate governance of ethical banks is designed to make sure that ethics is effectively implemented within organizational structure and that it is strongly embedded in the culture of the bank. Capital structure often reflects considerations about mission protection and preservation in the realm of competitive financial markets. Until the recent phenomena of benefit corporations, current corporate and financial legislation makes mission-oriented businesses vulnerable to profit-oriented shareholders that could deviate the organisation from its path. Ethical banks often use an ownership structure that is able to protect their mission

$5 \quad$ Formula of Universal Law reads: "act only in accordance with that maxim through which you at the same time can will that it become a universal law," (Kant, 1785, p. 421) and Formula of the End in Itself reads "act so that you use humanity, as much in your own person as in the person of every other, always at the same time as end and never merely as means." $(1785$, p. 429)

6 A free-rider problem or tragedy of commons are well-known examples where the formula is violated.

$7 \quad$ Negative criteria work simply as a blacklist of areas which are not financed under any condition and positive criteria is a set of guidelines about which areas are preferable. 
or build in a mechanism that shall provide a certain level of protection. ${ }^{8}$ Further arguments for mission preservation are provided, for instance, by Dyllick and Hockerts (2002) who found that doing business responsibly has positive effect on satisfaction of customers and, in addition, is able to shape the culture of community it resides in. Bhattacharya, et al. (2008) top up with their conclusions that responsibility improves retention of talent and makes life of employees more satisfactory.

\section{Figure 1 | Net Interest Income, Revenue Margin, Loan Losses of Ethical Banks and their Peers in the 2003-2013 Period}

(a) Net Interest Income (in \%)

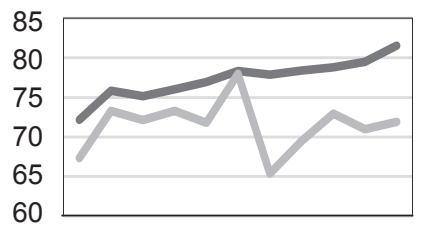

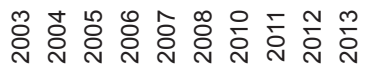

(b) Revenue Margin (in \%)

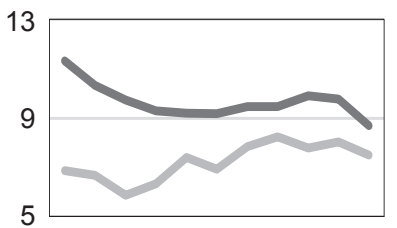

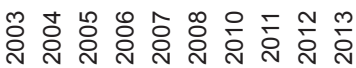

(c) Loan Losses (in \%)

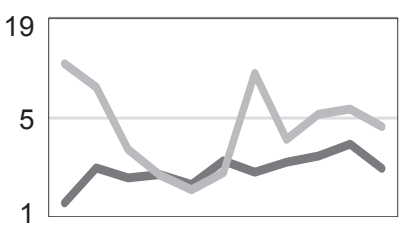

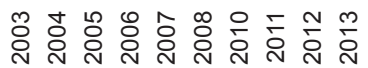

EBs Peers

Source: Authors based on Bankscope

Note: $\mathrm{EB}$ - ethical banks, Peers - peers of ethical banks (i.e. conventional banks)

For completeness of the picture, we present three charts comparing ethical banks (EBs) with their peers. ${ }^{9}$ Figure 1 (a) shows that ethical banks tend to have higher percentage of net interest income as share of total revenue than conventional banks and indirectly confirms the affinity of ethical banks to serve real economy. Although ethical banks have relatively high cost-to-income ratio - values around $80 \%$ are not an exception - they are also able to generate sufficient revenue margin ${ }^{10}$ to counter-balance that (see Figure 1 (b)). It does not inevitably mean that products and services offered by ethical banks are more expensive, we should consider that they often serve markets with un(der)banked population that are generally riskier and the revenue margin may reflect the conditions. Despite the higher risk profile, ethical banks maintain lower and more stable values of loan losses as visualized in Figure 1 (c). The origin of the favourable results likely lies in the more demanding credit assessment process that may also drive the higher cost-to-income ratio values.

\section{Data Analysis}

The data used in this research comes exclusively from the Bankscope database. Although the database gives us an extensive range of well comparable data there are some limitations.

8 A number of ethical banks have a cooperative structure where each member has one vote, or there are examples where the shares are managed by a foundation that ensures mission alignment in values between shareholders and the bank. Only a few ethical banks are publicly traded.

9 Two closest peers are picked for each ethical bank in the sample by asset size in countryspecialisation clusters.

10 Calculated as total revenue to total assets. 
Duplicate entries or missing variables are expected obstacles that we are able to control for or fix. A more serious constraint is the fact that, since ethical banks are usually smaller local banking institutions, there is a number of banks that would fit our criteria but do not have a Bankscope entry. Despite the limitations we face, the size of our final dataset large enough to allow for a robust analysis.

Far the most serious limitation becomes obvious when it comes down to identification of ethical banks. Of course, it would be ideal to measure the level of ethics within each bank on a set of standardized and easily comparable metrics - and there is a growing number of sustainability or corporate social responsibility reports across the banking industry that claim to provide the required information. Unfortunately, these reports often provide only partial information that certainly does not allow us to draw a line between the ethical and conventional approach. ${ }^{11}$ Since most information needed for an appropriate assessment whether a bank applies ethics throughout its business model remains publicly unavailable we have to search for available and reliable proxy classification.

\subsection{Dataset: Sample and Slicing}

For definition of our sample of ethical banks we rely on third party assessments that go in line with the previously introduced principles and values of ethical banking. The chosen third parties are membership organisations, sustainable or ethical investment companies, a certification company, and banking networks. They benefit from access to confidential information about their members and investments and their analysis can go much deeper than any other based on publicly available information.

The set of parties chosen for the proxy assessment is based on interviews with experts from the ethical banking sector and supported with authors' research. It is apparent that this approach is far from ideal and does not provide us with an exhaustive list of institutions - it is estimated there are approximately 2,000 banks "focused on meeting human needs in the real economy" (SFRE Fund, 2015) - but we believe that it covers all main players in the field.

Table 2 | Ethical Banking Organizations

\begin{tabular}{|l|l|}
\hline Access Microfinance Holding & Global Alliance for Banking on Values \\
\hline Accion & $\begin{array}{l}\text { International Association of Investors in the } \\
\text { Social Economy }\end{array}$ \\
\hline Aga Khan Fund for Economic Development & responsability \\
\hline B Corporation & Triodos Investment Management \\
\hline European Federation of Ethical and Alternative Banks & Women's World Banking \\
\hline FINCA & \\
\hline
\end{tabular}

Source: Authors

11 One example among many, BNP Paribas presents itself as a "responsible bank" in its corporate social responsibility report (BNP Paribas, 2013) while, on the other hand, it makes unlawful transactions with countries under US sanctions (The United States Department of Justice, 2015). On the other side of the spectrum stand some Ethical Banks that present all their loans publicly, e.g. Charity Bank or Triodos Bank. 
For consistency in our sample we apply the following criteria: [1] to be affiliated to at least one of the organisations enumerated in Table 2; [2] to hold a banking licence; [3] not to be a government-owned entity; [4] not to be a holding company; [5] to have assets over USD 50 million in 2012; and [6] to have an entry in the Bankscope database. Under these assumptions we identified 69 banking institutions around the world (Table 3). The full dataset then contains all banks from the countries with at least one ethical bank that meet criteria [1]-[6]. Further refinement is done through slicing the dataset by size and by geography-specialisation. This approach enables us to build suitable dataset around the diverse sample of ethical banks, ensure good comparability of data and robustness of results. As we proceed, slices that do not contain any sample ethical bank are left out.

Table 3 | Sample Description - Asset Size an Observation

\begin{tabular}{|l|c|c|}
\hline \multirow{2}{*}{ In USD billion } & \multicolumn{2}{|c|}{ Ethical banks (EBs) } \\
\cline { 2 - 3 } & $\mathbf{2 0 1 2}$ & $\mathbf{2 0 0 3 - 2 0 1 3}$ \\
\hline Average asset size & 1.94 & 1.26 \\
\hline Minimum asset size & 0.05 & 0.01 \\
\hline Maximum asset size & 19.69 & 22.43 \\
\hline Total assets & 133.73 & 674.79 \\
\hline Number of observations & 69 & 537 \\
\hline
\end{tabular}

Source: Authors based on Bankscope

With an average size of USD 1.94 billion in 2012 and maximum asset size of USD 22.4 billion over the studied time period it is noticeable that comparing ethical banks with big banks would not give us very representative results. Therefore we cut off GlobalSystematically Important Financial Institutions ("G-SIFIs") and Regional-Systematically Important Financial Institutions ("R-SIFIs") 12 as summarized in Table 4. All data used further on relates solely to the "Non-SIFIs" group that outnumbers the other two groups although in terms of assets it is relatively the smallest. Incomparability of the three groups is demonstrated in percentages of Loans, Trading book, Stable funding or Equity as share of Total Assets as well as Return on Equity and its volatility. Differences between the groups follow simple pattern in all variables and reveal major weaknesses of the larger banks.

The geography-specialisation slicing is a next step in refining our dataset and is driven by the expectation that different conditions across the two dimensions could negatively affect validity of our results. Geography is based on the IMF classification of Advanced Economies (International Monetary Fund, 2012). Since $66.5 \%$ of banks in the Advanced Economies subset come from the United Stated we separate them out as another geographic group. All remaining countries that do not belong to Advanced Economies are marked by us as Emerging Economies. Specialisations of banks are then taken as defined in Bankscope.

12 G-SIFIs are arbitrarily defined as having more than USD 1,000 billion in assets and R-SIFIs as having assets in interval of USD 100 billion and USD 1,000 billion. For more details on G-SIFIs we refer to, for example, Bongini et al. (2015) or Śútorová and Teplý (2014). 
The final dataset comprises of five slices - [1] US Commercial Banks, [2] Advanced Economies Commercial Banks, [3] Advanced Economies Cooperative Banks, [4] Emerging Economies Commercial Banks and [5] Emerging Economies Micro-Financing Institutions.

Table 4 | Dataset Description and Grouping

\begin{tabular}{|c|c|c|c|}
\hline In USD billion & $\begin{array}{l}\text { "Non-SIFIs" } \\
\text { As }<100\end{array}$ & $\begin{array}{c}\text { "R-SIFIs" } \\
100<\text { As }<1,000\end{array}$ & $\begin{array}{l}\text { "G-SIFIs" } \\
1,000<\text { As }\end{array}$ \\
\hline Sum of Total Assets & $20,646.28$ & $26,322.26$ & $31,131.98$ \\
\hline Average of Total Assets & 1.98 & 360.58 & $1,729.55$ \\
\hline Number of banks & 10,402 & 73 & 18 \\
\hline $\begin{array}{l}\text { Average in per cent to Total } \\
\text { Assets }\end{array}$ & $\begin{array}{l}\text { "Non-SIFIs" } \\
\text { As }<100\end{array}$ & $\begin{array}{c}\text { "R-SIFIs" } \\
100<\text { As }<1,000\end{array}$ & $\begin{array}{l}\text { "G-SIFIs" } \\
1,000<\text { As }\end{array}$ \\
\hline Loans & 61.04 & 54.79 & 40.40 \\
\hline Trading book & 0.57 & 5.73 & 10.00 \\
\hline Stable funding & 78.67 & 60.62 & 50.28 \\
\hline Equity & 11.08 & 6.38 & 5.64 \\
\hline Average in per cent & $\begin{array}{l}\text { "Non-SIFIs" } \\
\text { As }<100\end{array}$ & $\begin{array}{c}\text { "R-SIFIs" } \\
100<\text { As }<1,000\end{array}$ & $\begin{array}{l}\text { "G-SIFIs" } \\
1,000<\text { As }\end{array}$ \\
\hline Return on Equity & 6.44 & 5.46 & 2.48 \\
\hline sd(Return on Equity) & 5.93 & 6.97 & 7.04 \\
\hline
\end{tabular}

Source: Authors based on Bankscope

\subsection{Variables}

Two categories of variables are used in the empirical analysis - studied and control variables. The former group consists of a dummy variable Ethics for ethical banks as defined in the previous sections and dependent variables for profitability and volatility, in our case Return on Assets, Return on Equity and their 5-year standard deviations. We study both profitability measures as each of them provides information from a different angle - Return on Assets tells the story from the bank's perspective and reflects its operational performance while Return on Equity represents shareholders' point of view and its levels might be impacted by capital strategy of a bank.

We selected control variables based on papers that studied specifics of various banking business models, including the effects on profitability and volatility, also using the Bankscope database (Roengpitya et al., 2014; Ayadi and De Groen, 2014). ${ }^{13}$ Their original set of variables is narrowed down by excluding variables with a large portion of missing values and leaves us with Loans, Deposits and Equity. We further add a variable of Net Interest Margin to represent income statement side and, with regards to the findings from dataset slicing, we include a variable for size and a dummy for geography-specialisation clusters. A final list of variables with their description is summarized in Table 5.

13 Although Roengpitya, Tarashev, \& Tsatsaronis (2014) were using Bankscope database we omit their Trade variable from our analysis for ambiguity in definition and keep only Trading book to represent the trading part of balance sheet. 
Table 5 | Variables

\begin{tabular}{|l|l|}
\hline Variables & Description (Bankscope names) \\
\hline Return on Assets & Net Income / 2-year end average of Total assets \\
\hline Return on Equity & Net Income / 2-year end average of Total equity \\
\hline sd(Return on Assets) & 5-year standard deviation of Return on Assets \\
\hline sd(Return on Equity) & 5-year standard deviation of Return on Equity \\
\hline Ethics & Dummy variable for ethical banks as defined above \\
\hline Loans & Gross loans / Total assets \\
\hline Deposits & Consumer deposits / Total assets \\
\hline Equity & Total equity / Total assets \\
\hline Net Interest Income & Net Interest Income / Total revenue \\
\hline Size & Natural logarithm of Total assets \\
\hline Advanced Economies Cooperative Banks & $\begin{array}{l}\text { Dummy variable for banks belonging to subsets } \\
\text { Advanced Economies AND Cooperative Banks }\end{array}$ \\
\hline Advanced Economies Commercial Banks & $\begin{array}{l}\text { Dummy variable for banks belonging to subsets } \\
\text { Advanced Economies AND Commercial Banks }\end{array}$ \\
\hline Emerging Economies Micro-Financing \\
Institutions & $\begin{array}{l}\text { Dummy variable for banks belonging to subsets } \\
\text { Emerging Economies AND Micro-Financing } \\
\text { Institutions }\end{array}$ \\
\hline Emerging Economies Commercial Banks & $\begin{array}{l}\text { Dummy variable for banks belonging to subsets } \\
\text { Emerging Economies AND Commercial Banks }\end{array}$ \\
\hline
\end{tabular}

Source: Authors based on Bankscope and IMF

\section{Methodology}

Given characteristics of the dataset and studied variables, panel data regressions using random effects were deemed to be the most suitable estimation method. A Breusch-Pagan test confirms panel data but Hausman test suggests to use a within estimation because of present suspicion for correlation between an individual effect and independent variables. For the studied variable is by definition time-invariant ${ }^{14}$, we adopt an approach suggested by Bell and Jones (2015) combining within and between estimation. The Within-Between estimation builds on work of Mundlak (1978) whose approach is in current studies referred to as "Correlated Random Effects" (Wooldridge, 2010). The name already suggests that the approach relaxes the assumption of no correlation between an individual effect $c_{i}$ and independent variables, $E\left(c_{i} \mid x_{i t}\right)=0$. The Within-Between estimation goes a step further than the Correlated Random Effects to also control for a heterogeneity bias caused

14 Theoretically, Ethics is not necessarily time-invariant but in reality there are not enough time variant examples of banks that changed their approach to enable robust analysis. 
by the correlation; this approach in addition enables to model it and interpret separately the within and between effects (Bell \& Jones, 2015).

Table 6 provides the reader with a short overview how equations and error terms of the individual models differ; for more details on algebraic expressions and interrelation of the models see Schunck (2013).

Table 6 | An Overview of Random Effects Models

\begin{tabular}{|l|l|l|}
\hline & \multicolumn{1}{|c|}{ Model } & \multicolumn{1}{c|}{ Error Term } \\
\hline Random Effects & $y_{i t}=\beta_{0}+\beta_{1} x_{i t}+c_{i}+e_{i t}$ & $c_{i}+e_{i t}$ \\
\hline Correlated Random Effects & $y_{i t}=\beta_{0}+\beta_{1} x_{i t}+\pi \bar{x}_{i}+c_{i}+e_{i t}$ & $\pi \bar{x}_{i}+c_{i}+e_{i t}$ \\
\hline Within-Between & $y_{i t}=\beta_{0}+\beta_{1}\left(x_{i t}-\bar{x}_{i}\right)+\beta_{2} \bar{x}_{i}+c_{i}+e_{i t}$ & $c_{i}+e_{i t}$ \\
\hline
\end{tabular}

Source: Authors based on Schunck (2013)

The Within-Between model including our set of variables described in Table 5 can be summarized as follows:

$$
y_{i t}=\beta_{0}+\beta_{1}\left(x_{i t}-\bar{x}_{i}\right)+\beta_{2} z_{i}+\beta_{3} \bar{x}_{i}+c_{i}+e_{i t},
$$

where $y_{i t}$ performance of a bank $i$ in year $t$,

$x_{i t}$ vector of independent variables for a bank $i$ in year $t$,

$\bar{x}_{i} \quad$ vector of mean independent variables for a bank $i$ in year $t$ [Between],

$\left(x_{i t}-\bar{x}_{i}\right)$ vector of demeaned independent variables for a bank $i$ in year $t$ [Within],

$c_{i}$ vector of bank-specific error terms,

$e_{i t}$ vector of error terms.

We run four separate estimations to test our hypothesis on the four dependent variables $y_{i t^{*}}$ Those estimations have the same form and each regression equation consists of the studied dummy variable for ethical banks and control variables. All dummy variables are timeinvariant and therefore we can observe only their Between effects.

A structure of the Within-Between model enables us to duplicate the Hausman test and check whether the chosen specification is appropriate. Unlike the popular Hausman test, this technique has the advantage that it accounts for specifics of the chosen model. The original Hausman test by definition checks whether the Within- and Betweenestimates are equal, as it holds for the regular Random Effects model, and an identical test can, therefore, be conducted by testing $\beta_{1}=\beta_{3}$ from the Within-Between model (Gould, 2001). Results of the estimation advocate for correct specification and neither demeaned nor mean independent variables of the Within-Between model express any collinearity that could disqualify the chosen method. Utilising suitable dummy variables will help us to rule out the effects of the geography-specialisation categories that could otherwise cause a heterogeneity bias. Besides the control variables, remaining errors are clustered by country to provide robust standard errors, which are at the same time robust to a potential serial correlation bias (Hoechle, 2007).

Our hypothesis that ethical banks are less profitable in terms of Return on Asset and Return on Equity but they experience lower volatility in time technically represent alternative hypothesis that yet need to be translated into testable null hypothesis. The null 
will then read such as the use of ethics cause higher profitability and/or higher volatility for banking institutions and will be tested in post-estimation such as $H_{0}: \beta_{\text {Ethics }} \geq 0$ for all specified models. If a $p$-value is lower than a certain significance level, the null hypothesis is rejected which would confirm the initial (alternative) hypothesis.

\section{Results and Findings}

Estimations presented in Table 7 provide results for all four dependent variables under study. Applying the same model across all the profitability and volatility measures could have been troublesome but estimation statistics show a good fit for all columns. Nonetheless, as values of $\chi^{2}, \sigma_{u}^{2}$ or $\sigma_{e}^{2}$ indicate, Return on Assets models show relatively better specification than the ones for Return on Equity. The Within-Between method is characterized by a double set of time varying variables that has to be accounted for in interpreting the results. Within variables $\left(x_{i t}-\bar{x}_{i}\right)$ are marked with $W$ - prefix and Between variables $\bar{x}_{i}$ with $B$-.

\subsection{Empirical Analysis}

Although the method allows for modelling a number of elements that would otherwise fall into the unobservable term, our focus stays on Ethics. The studied variable is insignificant in both profitability and volatility when measured for Return on Assets. It also remains insignificant for profitability in terms of Return on Equity but there is a negative effect of Ethics when modelling volatility of Return on Equity. The negative effect tells us that application of ethics throughout bank's operations reduces volatility over time by approximately $4.37 \%$. The result falls into a $10 \%$ significance level with a standard two-side z-test. If we do a one-sided test with $H_{0}: \beta_{\text {Ethics }} \geq 0$ we are able to reject the null hypothesis at a 5\% significance level. In other words, banks applying ethics are less volatile than others in terms of Return on Equity.

The rest of the models reveal some more information about the control variables. Equity estimates in the Return on Assets model are both positive suggesting that banks with higher capital ratio perform better than others (Between effect of 6.70\%) and increase of Equity in a particular bank is also correlated with higher Return on Assets (Within effect of 3.01\%). Similarly for Size, larger banks in general tend to have higher profitability. Interestingly, Loans have a negative Between effect on Return on Assets while their Within effect is positive. This seemingly ambiguity is not exceptional and can be interpreted. ${ }^{15}$ In this case it indicates that an increase in Loans within a bank increases Return on Assets while, in general, banks with higher Loans tend to have lower Return on Assets. Inputting average values for our dataset to the equation shows the overall effect of Loans is more likely to be negative.

The Return on Equity estimation suggests that larger banks (an effect of B-Size) have higher profitability in terms of Return on Equity while, on the other hand, banks with higher levels of Loans and, quite understandably, with higher levels of B-Equity incline to exhibit lower Return on Equity. The Within estimator for Deposits shows a negative sign, however, with minimal economic significance after inputting dataset average values.

15 Explaining the opposite signs of Within and Between estimates is easier for dummy variables. Let us take, for instance, an effect of living in urban areas on wage. If the Within estimator has a negative sign and the Between estimator has a positive sign then it can be interpreted as: "moving to an urban area has a negative effect on income, individuals who generally live in the city tend to earn more". (Bell and Jones, 2015). 
Table 7 | Within-Between Effects Estimations

\begin{tabular}{|c|c|c|c|c|}
\hline $\begin{array}{l}\text { B } \\
\text { (Std.Err.) }\end{array}$ & $\begin{array}{c}\text { Return } \\
\text { on Asssets } \\
\text { (1) }\end{array}$ & $\begin{array}{c}\text { sd(Return } \\
\text { on Asssets) } \\
(2)\end{array}$ & $\begin{array}{c}\text { Return } \\
\text { on Equity } \\
\text { (3) }\end{array}$ & $\begin{array}{c}\text { sd(Return } \\
\text { on Equity) } \\
\text { (4) }\end{array}$ \\
\hline Ethics & $\begin{array}{r}-0.00222 \\
(0.00301)\end{array}$ & $\begin{array}{r}0.00196 \\
(0.00176)\end{array}$ & $\begin{array}{r}-0.00819 \\
(0.01562)\end{array}$ & $\begin{array}{l}-0.04374^{*} \\
(0.02521)\end{array}$ \\
\hline W-Loans & $\begin{array}{l}0.00882^{* * *} \\
(0.00300)\end{array}$ & $\begin{array}{l}-0.00627^{* * *} \\
(0.00120)\end{array}$ & $\begin{array}{r}0.06910 \\
(0.05650)\end{array}$ & $\begin{array}{r}-0.09438 \\
(0.12776)\end{array}$ \\
\hline W-Deposits & $\begin{array}{r}0.00085 \\
(0.00255)\end{array}$ & $\begin{array}{r}0.00065 \\
(0.00216)\end{array}$ & $\begin{array}{l}-0.06477^{* *} \\
(0.02971)\end{array}$ & $\begin{array}{r}0.04659 \\
(0.07651)\end{array}$ \\
\hline W-Equity & $\begin{array}{l}0.03013^{* * * *} \\
(0.00952)\end{array}$ & $\begin{array}{l}-0.00481 \\
(0.00567)\end{array}$ & $\begin{array}{r}-0.00056 \\
(0.08177)\end{array}$ & $\begin{array}{l}-0.43931 \\
(0.33594)\end{array}$ \\
\hline W-Net Interest Income & $\begin{array}{l}-0.00784 \\
(0.00983)\end{array}$ & $\begin{array}{r}-0.00203 \\
(0.00155)\end{array}$ & $\begin{array}{l}-0.02701 \\
(0.08847)\end{array}$ & $\begin{array}{r}-0.06885 \\
(0.04216)\end{array}$ \\
\hline W-Size & $\begin{array}{r}0.00014 \\
(0.00054)\end{array}$ & $\begin{array}{l}-0.00055 \\
(0.00042)\end{array}$ & $\begin{array}{l}-0.00236 \\
(0.00436)\end{array}$ & $\begin{array}{l}-0.05370 \\
(0.06604)\end{array}$ \\
\hline B-Loans & $\begin{array}{l}-0.00628^{* *} \\
(0.00187)\end{array}$ & $\begin{array}{r}0.00169 \\
(0.00268)\end{array}$ & $\begin{array}{l}-0.03356^{* *} \\
(0.01133)\end{array}$ & $\begin{array}{r}-0.00607 \\
(0.03010)\end{array}$ \\
\hline B-Deposits & $\begin{array}{r}-0.00035 \\
(0.00261)\end{array}$ & $\begin{array}{r}0.00439 \\
(0.00308)\end{array}$ & $\begin{array}{r}0.02213 \\
(0.01591)\end{array}$ & $\begin{array}{r}0.05101 \\
(0.06791)\end{array}$ \\
\hline B-Equity & $\begin{array}{l}0.06695^{* * * *} \\
(0.00750)\end{array}$ & $\begin{array}{l}0.06622^{* * * *} \\
(0.00582)\end{array}$ & $\begin{array}{r}-0.04391^{*} \\
(0.02390)\end{array}$ & $\begin{array}{l}-0.15691 \\
(0.12324)\end{array}$ \\
\hline B-Net Interest Income & $\begin{array}{l}-0.01188 \\
(0.00795)\end{array}$ & $\begin{array}{l}-0.01155^{* * *} \\
(0.00275)\end{array}$ & $\begin{array}{r}-0.05445 \\
(0.03926)\end{array}$ & $\begin{array}{l}-0.06524^{*} \\
(0.03343)\end{array}$ \\
\hline B-Size & $\begin{array}{l}0.00097^{* * *} \\
(0.00025)\end{array}$ & $\begin{array}{r}0.00007 \\
(0.00031)\end{array}$ & $\begin{array}{l}0.00598^{* * * *} \\
(0.00179)\end{array}$ & $\begin{array}{r}0.00417 \\
(0.00529)\end{array}$ \\
\hline $\begin{array}{l}\text { Advanced Economies } \\
\text { Cooperative Banks }\end{array}$ & $\begin{array}{l}-0.00493^{* * *} \\
(0.00065)\end{array}$ & $\begin{array}{l}-0.00200^{* * *} \\
(0.00040)\end{array}$ & $\begin{array}{l}-0.04200^{* * *} \\
(0.00402)\end{array}$ & $\begin{array}{l}-0.03104^{* * *} \\
(0.01192)\end{array}$ \\
\hline $\begin{array}{l}\text { Advanced Economies } \\
\text { Commercial Banks }\end{array}$ & $\begin{array}{l}-0.00848^{* * *} \\
(0.00223)\end{array}$ & $\begin{array}{r}0.00018 \\
(0.00120)\end{array}$ & $\begin{array}{l}-0.04466^{* * *} \\
(0.01157)\end{array}$ & $\begin{array}{r}0.01284 \\
(0.01715)\end{array}$ \\
\hline $\begin{array}{l}\text { Emerging Economies Micro- } \\
\text { Financing Institutions }\end{array}$ & $\begin{array}{l}0.01298^{* * * *} \\
(0.00374)\end{array}$ & $\begin{array}{c}0.00598^{*} \\
(0.00305)\end{array}$ & $\begin{array}{l}0.09132^{* * *} \\
(0.02344)\end{array}$ & $\begin{array}{l}0.09939 * * \\
(0.04089)\end{array}$ \\
\hline $\begin{array}{l}\text { Emerging Economies } \\
\text { Commercial Banks }\end{array}$ & $\begin{array}{l}-0.00301 \\
(0.00326)\end{array}$ & $\begin{array}{r}0.00153 \\
(0.00143) \\
\end{array}$ & $\begin{array}{r}0.00374 \\
(0.01445) \\
\end{array}$ & $\begin{array}{l}0.10465^{* *} \\
(0.05296)\end{array}$ \\
\hline Intercept & $\begin{array}{r}-0.00304 \\
(0.01229) \\
\end{array}$ & $\begin{array}{r}0.00157 \\
(0.00911) \\
\end{array}$ & $\begin{array}{r}0.02105 \\
(0.06445) \\
\end{array}$ & $\begin{array}{r}0.00228 \\
(0.17171) \\
\end{array}$ \\
\hline Number of groups & 8,809 & 8,579 & 8,809 & 8,579 \\
\hline Number of observations & 81,415 & 78,557 & 81,415 & 78,557 \\
\hline$X^{2}$ & $3,505.019$ & $3,843.801$ & 724.335 & 331.730 \\
\hline$P>X^{2}$ & 0.000 & 0.000 & 0.000 & 0.000 \\
\hline$\sigma_{u}^{2}$ & 0.018 & 0.010 & 0.088 & 0.391 \\
\hline$\sigma_{e}^{2}$ & 0.016 & 0.009 & 0.202 & 0.533 \\
\hline$\rho$ & 0.549 & 0.551 & 0.160 & 0.350 \\
\hline \multicolumn{5}{|l|}{$H_{0}: \beta_{\text {Ethics }} \geq 0$} \\
\hline$\left(P>X^{2}\right)$ & 0.23 & 0.867 & 0.300 & 0.041 \\
\hline
\end{tabular}

Note: Significance levels: ${ }^{*} 10 \%,{ }^{* *} 5 \%,{ }^{* * *} 1 \%$

Source: Authors based on Bankscope 
Volatility measures are to a certain extent correlated with share of Net Interest Income to Total Revenue. Its effect is both statistically and economically significant; on average it decreases volatility of Return on Assets by $0.88 \%$ and $4.98 \%$ for Return on Equity. Volatility of Return on Assets decreases if there is an increase of Loans within a bank but, maybe surprisingly, is higher for banks with more Equity.

Geography-specialisation categories have confirmed to be a suitable distinction of various market conditions and banking business models in our dataset; moreover, if we excluded the geography-specialisation dummies we would face an omitted variable bias. ${ }^{16}$ Estimates for the categories where US commercial banks serve as a baseline have expected and understandable effects. Both types of banks from Advanced Economies are less profitable than US commercial banks as measured with either Return on Assets or Return on Equity; more economically significant negative effects appear for commercial banks (lower by $0.85 \%$ and $4.47 \%$, respectively) than for cooperative banks (lower by $0.49 \%$ and $4.20 \%$, respectively). In similar fashion, cooperative banks from Advanced Economies perform better than commercial banks in terms of volatility; coefficients suggest that their volatility is by $0.20 \%$ and $3.10 \%$ lower for Return on Assets and Return on Equity, respectively. Emerging Economies Micro-Financing Institutions, on the other hand, exhibit higher profitability than benchmark. However, their profitability is more volatile; $9.13 \%$ higher Return on Assets would likely be compensated with $9.93 \%$ higher volatility. ${ }^{17}$

\subsection{Results Summary}

Modelling the profitability and volatility measures on Ethics and other control variables partially confirmed the hypothesis that banks applying ethics have lower volatility in profits than other banks; we found the significant effect of the studied variable only in the model with volatility of Return on Equity. The Ethics dummy remained statistically insignificant for all the other dependent variables. However, also the insignificance can be interpreted and give us some valuable information; we were not able to reject that the use of ethics makes a bank more profitable than its peers.

The dataset decomposition proved to be useful as demonstrated by robustness of the panel data regressions. Effects of the geography-specialisation dummies suggest that there remain significant differences in profitability and volatility between the clusters although we exclude G-SIFIs and R-SIFIs. Contrarily, it is difficult to draw general conclusions from estimates of the financial profile control variables as they primarily had a function of a statistical tool here.

\subsection{Further Research Opportunities}

To date there has not been much research done on application of ethics in banking, hence further research opportunities are numerous. First area that definitely deserves further research is the sample of ethical banks. Identification of banks applying ethics throughout their business models outside of the member organisations is still imperfect. There is

16 Sensitivity analysis reveals that especially exclusion of the Emerging Micro-Financing Institutions dummy would largely change estimates for Ethics.

17 The reader should be aware that comparison across models, i.e. the mentioned compensation between profitability and volatility, is used only for illustration as the two are parts of separate models. 
a potential for GABV Scorecard, a tool being developed by Global Alliance for Banking on Values, to establish a generally applicable definition for the field. The dataset could then be extended to more banks and countries. The largest group of further research opportunities lies in studied variables. Although profitability and volatility are a golden rule in researching financial performance, there are many other measures which could give new insights on application of ethics in banking; results for loan losses may serve as a fine example. Also researching patterns between ethics and capital structure or riskiness of loan portfolio may be an interesting opportunity. A completely new world awaits in nonfinancial metrics, as that would enable to study social and environmental outcomes and impact of the applied ethical standards.

\section{Conclusion}

In this paper, we contribute to the literature focusing on ethics in banking from both theoretical and empirical point of view. In the theoretical part we introduce values, principles and other ethical concepts defining the diverse universe of ethical banking models. Applied in practice, they may create the decisive competitive advantage for banks in the expected fight over customers with the strengthening non-bank Fintech-powered challengers.

In the empirical part, we investigate how ethics in banking business models affects their financial performance based on more than 80,000 bank-year observations for in 2003-2013. We apply the Within-Between estimation method to bank financial indicators of Return on Assets, Return on Equity and their respective volatilities. We argue that ethical banking is a viable competitor to conventional banking and that the ethical approach does not significantly affect profitability measured by either Return on Assets or Returns on Equity; it is worth noting that we could neither reject a one-sided hypothesis that ethical banks have higher profitability than their peers. More importantly, our research shows that ethical banking demonstrates lower volatility in Returns on Equity than the peers and therefore may be attractive to patient investors with longer-term investment horizons.

However, it is far beyond the scope of this paper to offer the whole picture of ethical banking and its impacts on customers and broader society or environment. We believe that the results will encourage other researchers as well as financial executives and investors to set off to further exploration of the ethical approach to banking. More research yet needs to be done but responsible banking institutions using finance in favour of society and environment may have a big potential for transforming the current financial system to better serve client's needs.

\section{References}

Acharya, V. A. et al. (2010). Regulating Wall Street: The Dodd-Frank Act and the New Architecture of Global Finance. New York: WILEY FINANCE.

Ayadi, R., De Groen, W. P. (2014). Banking Business Models Monitor 2014. Centre for European Policy Studies.

Bell, A., Jones, K. (2015). Explaining Fixed Effects: Random Effects Modeling of Time-Series Cross-Sectional and Panel Data. Political Science Research and Methods, 3(1), 133-153, http://dx.doi.org/10.1017/psrm.2014.7

Bhattacharya, C., Sen, S., Daniel, K. (2008). Using Corporate Social Responsibility to Win the War for Talent. MIT Sloan Management Review.

BNP Paribas (2013). Corporate Social Responsibility Report: Working Together as a Responsible Bank. BNP Paribas. 
Bongini, P., Nieri, L., Pelagatti, M. (2015). The Importance of Being Systemically Important Financial Institutions. Journal of Banking \& Finance, 50, 562-574, http://dx.doi.org/10.1016/j.jbankfin.2014.07.006

Dyllick, T., Hockerts, K. (2002). Beyond the Business Case for Corporate Sustainability. Business Strategy and the Environment, 11(2), 130-141, http://dx.doi.org/10.1002/bse.323

EBF (2015). Driving the Digital/ Transformation the EBF Blueprint for Digital Banking and Policy Change? The European Banking Federation. Available at: http://www.ebfdigitalbanking.eu Global Alliance for Banking on Values (2014). Real Economy - Real Returns: The Business Case for Sustainability Focused Banking. Global Alliance for Banking on Values.

Gould, W. (2001). What Is the Between Estimator? StataCorp. Available at: http://www.stata.com/ support/faqs/statistics/between-estimator

Hoechle, D. (2007). Robust Standard Errors for Panel Regressions with Cross-Sectional Dependence. The Stata Journal, 7(3), 281-312. Available at: http://www.stata-journal.com/ sjpdf.html?articlenum $=$ st0128

International Monetary Fund (2012). World Economic Outlook: Growth Resuming, Dangers Remain. Washington, DC: International Monetary Fund.

Kant, I. (1785). Groundwork for the Metaphysics of Morals. 2002 Ed. New Haven and London: Yale University Press.

Klinger, T., Teplý, P. (2014). Systemic Risk of the Global Banking System - An Agent-Based Network Model Approach. Prague Economic Papers, 23(1), 24-41, http://dx.doi. org/10.18267/j.pep.471

Mundlak, Y. (1978). Pooling of Time-Series and Cross-Section Data. Econometrica, 46(1), 69-85, http://dx.doi.org/10.2307/1913646

Roengpitya, R., Tarashev, N., Tsatsaronis, K. (2014). Bank Business Models. BIS Quarterly Review, 55-65. Available at: http://www.bis.org/publ/qtrpdf/r_qt1412g.htm

Schunck, R. (2013). Within and Between Estimates in Random-Effects Models: Advantages and Drawbacks of Correlated Random Effects and Hybrid Models. The Stata Journal, 13(1), 65-76. Available at: http://www.stata-journal.com/sjpdf.html?articlenum=st0283

Sen, A. (2000). On Ethics and Economics. Oxford: Blackwell Publishers Ltd.

Smith, A. (1759). The Theory of Moral Sentiments. 2000 Ed. New York: Prometheus Books.

Smith, A. (1776). An lquiry into the Nature and Causes of the Wealth of Nations. 2000 Ed. London: Electric Book Co.

SFRE Fund, (2015). New Fund with Ambition to Provide \$1 Billion Capital for New Banking Paradigm. Luxembourg: SFRE Fund. Available at: http://sfre.bluinc.co.uk/ new-fund-with-ambition-to-provide-1-billion-capital-fornew-banking-paradigm/

Sútorová, B., Teplý, P. (2014). The Level of Capital and the Value of EU Banks under Basel III. Prague Economic Papers, 23(2), 143-161, http://dx.doi.org/10.18267/j.pep.477

The United States Department of Justice (2015). BNP Paribas Sentenced for Conspiring to Violate the International Emergency Economic Powers Act and the Trading with the Enemy Act. Washington D.C.: The United States Department of Justice. Available at: http://www. justice.gov/opa/pr/bnp-paribas-sentenced-conspiring-violate-international-emergencyeconomic-powers-act-and

Wooldridge, J. M. (2010). Correlated Random Effects Models with Unbalanced Panels, World Business Council for Sustainable Development. Geneva: WBCSD. Available at: http://www.wbcsd.org/ 